\title{
Geochemistry of Oil Fields, East Java Basin: Biomarker Characterisation
}

\author{
Elok A Devi ${ }^{1 *}$, Faisal Rachman ${ }^{2}$ and Awang H Satyana ${ }^{3}$ \\ ${ }^{1}$ Intership of Eni, Indonesia \\ ${ }^{2}$ Joint Operating Body Pertamina-Petro China East Java, Indonesia \\ ${ }^{3}$ Special Task Force for Oil and Gas (SKK Migas), Indonesia
}

Submission: August 16, 2018; Published: October 12, 2018

*Corresponding author: Elok A Devi, Intership of Eni Indonesia, Indonesia, Email: elokannisadevi@gmail.com

\begin{abstract}
Biomarkers are molecular fossils derived from living organisms and these complex compounds are composed of carbon, hydrogen and other elements. Biomarkers show little or no change in chemical structure from their parent organic molecules in living organisms [1]. Biomarkers are very useful due to their complex structures, revealing precise information about the depositional origins. It has been recognized that biomarkers in oils and rock extracts reflect depositional environment [1-3]. Therefore, biomarkers are used to achieve the objectives in such study to know the characterization of oil samples.
\end{abstract}

Keywords: Fossils; Biomarkers; Oil; Isoprenoids; Marginal marine

\section{Introduction}

A study was conducted to analyze the oil characterizations in the oil Fields of East Java Basin (oil to oil correlation) based on biomarkers. The North East Java basin is located on the southeastern margin of a stable Sunderland micro continent, Indonesia. The biomarker data was obtained from GC and GC-MS analysis of normal alkanes, isoprenoids, triterpanes and steranes.

Every item of organic matter deposited in specific depositional environment or source facies developed a specific biomarker. In geochemistry characterization of oil samples, biomarkers were carried out by doing pattern matching analysis and finger printing analysis through various geochemical crossplots.

Pattern matching method was done by using chromatogram GC of n-alkane and isoprenoids (Figure 1) also fragmentogram GCMS of terpane m/z 191 and sterane m/z 217 (Figure 2). The pattern matching shows that all oils have a relatively similar pattern, indicating that all the oil samples came from one family with deltaic to marginal marine source facies.

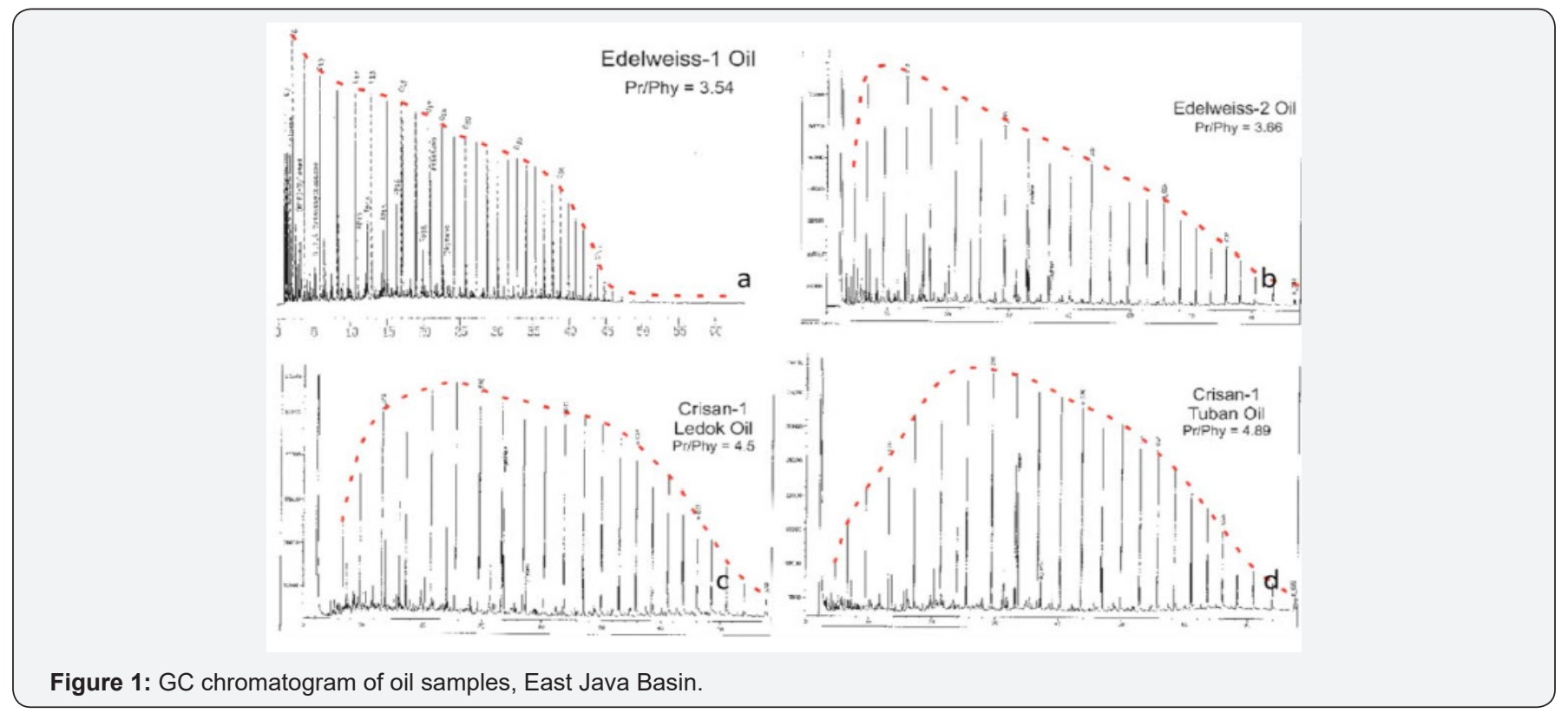




\section{Academic Journal of Polymer science}

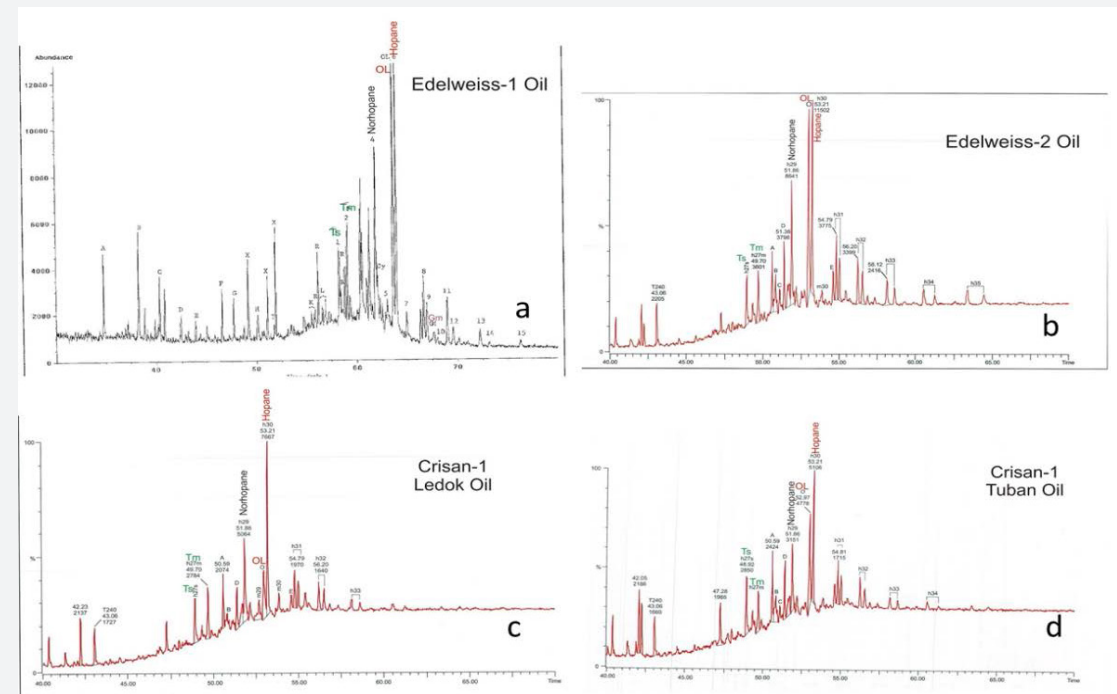

Figure 2: GCMS fragmentogram m/z 191 of oil samples, East Java Basin.

In addition, some biomarkers data from finger printing analysis that are used consist of:

A. Pristane/phytane ratio as an indicator of depositional environment. The results of this case study show that oil samples have pristane/phytane ratios greater than 2.0 and pristane/n-C17 ratios are roughly similar with range $0.66-0.84$, indicating deltaic or transitional with terrestrial input and deposition in a relatively sub-oxic to oxic environment (Figure 3).

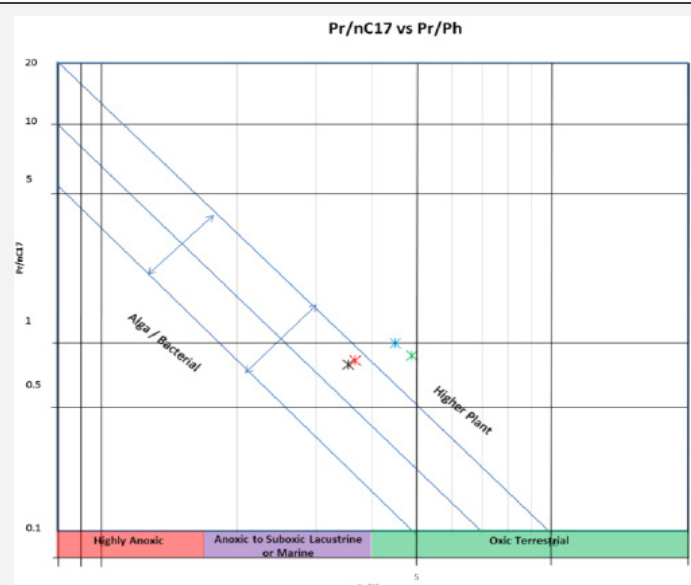

<Edeleweis:-1

x crisan-1 ledol

Crisan-1 Tuban

Figure 3: Plot of pristane/n-C17 versus pristane/phytane showing the depositional environment and the conditions of the studied oi samples [4].

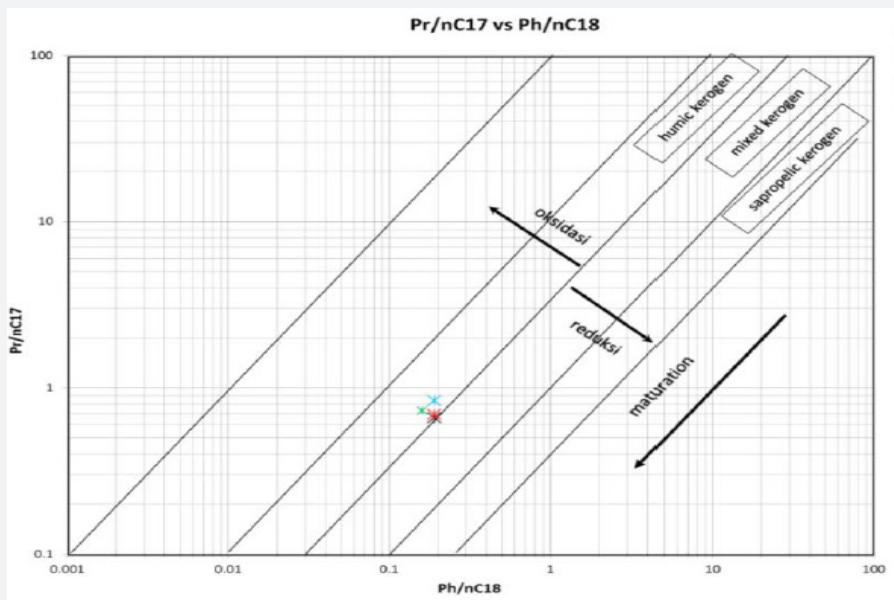

xEdelweiss-1

Crisan-1 Tuban 


\section{Academic Journal of Polymer science}

B. The resultant ratios pristane/n-C17 and phytane/n-C18 (isoprenoids/n-alkanes) of all oil samples range from 0.66 to 0.84 and 0.16 to 0.19 , respectively reflect that all the oils were from humic and mixed kerogen (organic facies), deposited under transitional environment with oxidation to reduction conditions and show a degree of maturation (Figure 4).

C. Total hopane/sterane ratio from 4 oils are the same type of predominantly sub-oxic to oxic terrestrial influence (Figure 5).

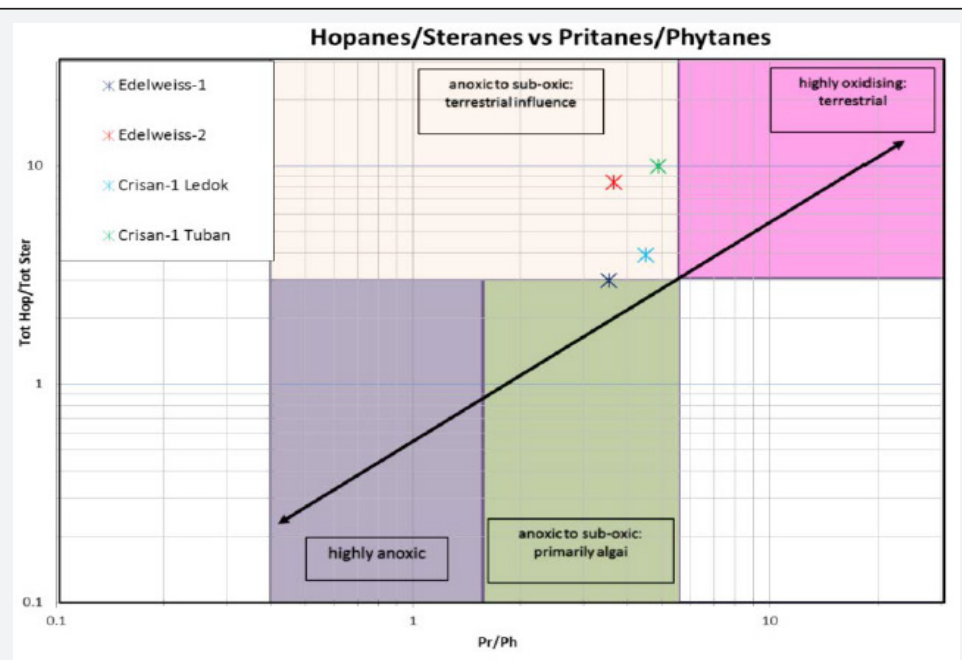

Figure 5: Plot of hopane/sterane versus pristane/phytane showing the organic source input and the environment condition of the studied oils (after Grantham, [5]).

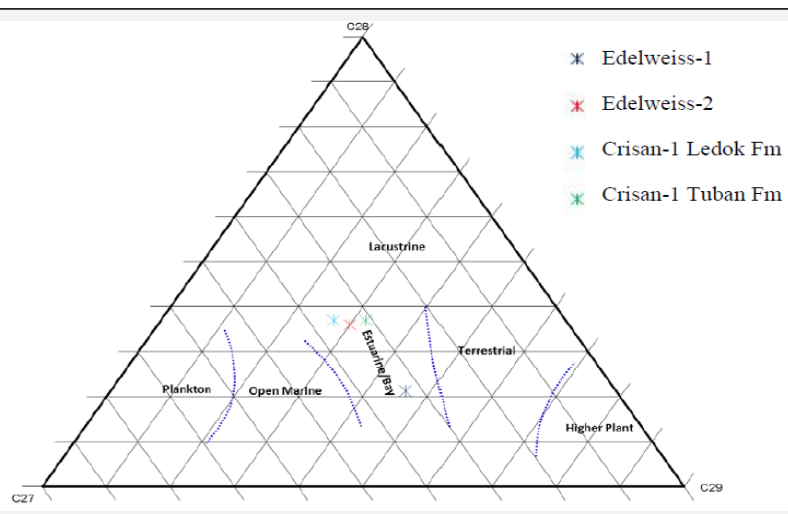

Figure 6: Ternary diagram of $\mathrm{m} / \mathrm{z} 217$ sterane C27-C28-C29 showing the depositional environment of the studied oil samples.

D. The ternary diagram of $\mathrm{m} / \mathrm{z} 217$ sterane C27-C28-C29 also show all the oils came from one family with a predominant estuarine or bay depositional environment (Figure 6).
Then, a crossplot of triterpane maturity parameter (Figure 7) show that all oil samples in the early mature stages [4,5].

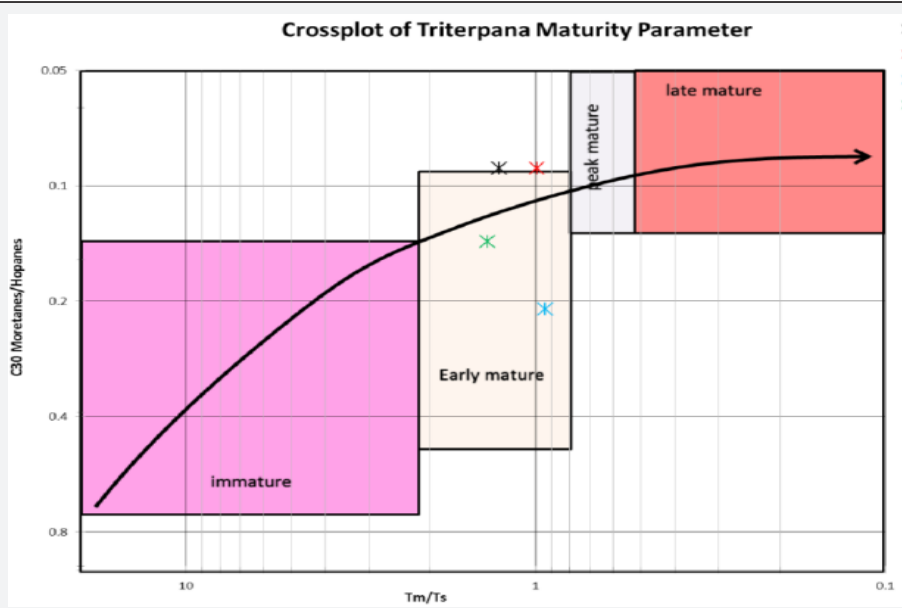

Xdelweiss-1

Edelweiss-2

Crisan-1 Ledok
Crisan-1 Tuban

Figure 7: Plot of pristane/phytane versus $\mathrm{C} 30$ moretane/hopane showing the maturity of the studied oils [1]. 


\section{References}

1. Peters KE, Moldowan JM (1993) The Biomarker Guide: Interpreting Molecular Fossils in Petroleum and Ancient Sediments. Prentice-Hall, Inc., Englewood Cliffs, USA.

2. Hunt JM (1997) Petroleum Geochemistry and Geology ( $2^{\text {nd }}$ edn). WH Freeman and Company, New York, USA, pp. 743.

3. Peters KE, Walters CC, Moldowan JM (2005) The Biomarker Guide (2 edn). Vol. I \& II Cambridge University Press, Cambridge, UK.

This work is licensed under Creative Commons Attribution 4.0 License

DOI: 10.19080/AJOP.2018.02.555578
4. Hwang, RJ, Heidrick T, Mertani B, (1998) Geochemical Indicators of Petroleum Migration in Central Sumatra, Exploration Technology, Exploration Rumbai, Indonesia.

5. Waples D, Machihara T (1991) Biomarkers for Geologist-A Practical Guide to the Application of Steranes and Triterpanes in Petroleum Geology. American Association Petroleum Geologist, USA.

\section{Your next submission with Juniper Publishers will reach you the below assets}

- Quality Editorial service

- Swift Peer Review

- Reprints availability

- E-prints Service

- Manuscript Podcast for convenient understanding

- Global attainment for your research

- Manuscript accessibility in different formats

( Pdf, E-pub, Full Text, Audio)

- Unceasing customer service

Track the below URL for one-step submission

https://juniperpublishers.com/online-submission.php 